\title{
Occurrence of two superoxide dismutases in Aeromonas hydrophila: molecular cloning and differential expression of the sodA and sodB genes
}

Laboratoire de Microbiologie ${ }^{1}$ and Laboratoire de Biologie du Développement ${ }^{2}$, Université des Sciences et Technologies de Lille, F-59655 Villeneuve d'Ascq Cedex, France

\author{
Valérie Leclère, ${ }^{1}$ Anne Chotteau-Lelièvre, ${ }^{2}$ Frédérique Gancel, ${ }^{1}$ \\ Marlène Imbert $^{1}$ and Roland Blondeau ${ }^{1}$
}

Author for correspondence: Valérie Leclère. Tel: +323204346 68. Fax: +32320436504. e-mail: Valerie.Leclere@univ-lille1.fr

\begin{abstract}
Aeromonas spp., considered as emerging opportunistic pathogens, belong to the family Vibrionaceae. Among the criteria currently used for their classification is the presence of a single FeSOD (iron-containing superoxide dismutase), which distinguishes them from Enterobacteriaceae. In this paper the cloning of the SodA and sodB genes encoding two different SODs in Aeromonas hydrophila ATCC 7966 is reported. The sodB gene encoded an FeSOD (196 amino acids, $21.5 \mathrm{kDa}$ ), was constitutively expressed and showed $75 \%$ homology with the E. coli FeSOD. The sodA gene encoded a protein of 206 amino acids (22.5 kDa) with MnSOD (manganese-containing SOD) activity and showed 55\% homology with the Escherichia coli MnSOD. The MnSOD of A. hydrophila was detected only during the stationary phase of growth under high aeration or when induced by lack of iron. Nevertheless, paraquat had no detectable effect on its production. The amino-terminal part of the Mncontaining protein contained a putative signal sequence which could permit a periplasmic localization.
\end{abstract}

Keywords: Vibrionaceae, MnSOD, FeSOD

\section{INTRODUCTION}

Antioxidant enzymes are essential for living cells, providing protection from reactive oxygen species such as superoxide, which cause oxidative damage to cell structures. Superoxide dismutases (SODs; EC 1.15.1.1) constitute a ubiquitous class of antioxidant defence metalloenzymes that catalyse the conversion of superoxide radical ion into dioxygen and hydrogen peroxide.

The SODs are classified according to the metal ion cofactor required for their activity: the copper-zinc type $(\mathrm{Cu} / \mathrm{ZnSOD})$, the manganese type (MnSOD), the iron type (FeSOD) (Fridovich, 1986) and the most recently described nickel type (NiSOD) (Youn et al., 1996). Bacteria contain one to three SOD enzymes, which can

Abbreviations: CDM, chemically defined medium; DIP, 2,2'-dipyridyl; $E D D A$, ethylenediamine di-(o-hydroxyphenylacetic acid); $P Q$, paraquat; SOD, superoxide dismutase.

The GenBank accession numbers for the sequences reported in this paper are AF317226 and AF317227. be expressed simultaneously. The facultative anaerobe Escherichia coli possesses three SODs which differ in their location and temporal expression. Both FeSOD and MnSOD are cytoplasmic. FeSOD is produced at a constant rate under aerobic and anaerobic conditions, but $\mathrm{MnSOD}$ is only synthesized aerobically and its presence is modulated by exposure to oxygen or intracellular $\mathrm{O}_{2}^{-}$or upon changes in growth phase (Demple, 1991; Compan \& Touati, 1993). The third E. coli SOD, containing $\mathrm{Cu} / \mathrm{Zn}$, is located within the periplasmic space (Benov et al., 1995).

Bacteria belonging to the genus Aeromonas are Gramnegative facultatively anaerobic rods displaying catalase and oxidase activities. They are currently classified in the family Vibrionaceae, but a separate family has been proposed on the basis of the $16 \mathrm{~S}$ rRNA cataloguing and rRNA-DNA hybridization results (Colwell et al., 1986). They are commonly found in aquatic environments and increasingly in ready-to-eat foods (Kirov, 1997). They are considered as emerging opportunistic pathogens associated with gastroenteritis and enterocolitis in humans (Merino et al., 1995). 
According to the description of the family Vibrionaceae in Bergey's Manual of Systematic Bacteriology (Baumann \& Schubert, 1984), Aeromonas expresses a single FeSOD and this feature tends to discriminate between the families Vibrionaceae and Enterobacteriaceae.

In this study we identified and characterized the genes encoding SODs from Aeromonas hydrophila and compared their expression to that of the E. coli SODs.

\section{METHODS}

Strains, media and culture conditions. The strains and plasmids used in this study are listed in Table 1. E. coli and A. hydrophila were grown in LB medium (per litre: tryptone $10 \mathrm{~g}$; yeast extract $5 \mathrm{~g} ; \mathrm{NaCl} 5 \mathrm{~g} ; \mathrm{pH} 7 \cdot 2$ ) at $30^{\circ} \mathrm{C}$. For ironlimited cultures, the glassware was treated with $10 \%(\mathrm{v} / \mathrm{v})$ nitric acid, and the cells were grown either (i) in LB medium containing iron chelators (each at $100 \mu \mathrm{M})$ : DIP $\left(2,2^{\prime}-\right.$ dipyridyl), EDDA [ethylenediamine di-(o-hydroxyphenylacetic acid)], desferrioxamine B (Desferal; Ciba-Geigy) or (ii) in $\mathrm{CDM}$ (per litre: glucose $5 \mathrm{~g} ;\left(\mathrm{NH}_{4}\right)_{2} \mathrm{HPO}_{4} 1 \mathrm{~g} ; \mathrm{K}_{2} \mathrm{HPO}_{4}$ $4 \mathrm{~g} ; \mathrm{KH}_{2} \mathrm{PO}_{4} 2.7 \mathrm{~g}$ ) made with Chelex-100-treated distilled water and supplemented after sterilization with sulfate salts of magnesium $(830 \mu \mathrm{M})$ and manganese $(40 \mu \mathrm{M})$. Broth cultures were grown under high aeration $(100 \mathrm{ml}$ medium in a 1 litre flask with vigorous rotary shaking at 100 r.p.m.) or under low aeration $(100 \mathrm{ml}$ medium in a $300 \mathrm{ml}$ flask with gentle swirling at 40 r.p.m.).

Cloning and sequencing of sod genes. Chromosomal DNA from A. hydrophila was prepared from an overnight culture in $5 \mathrm{ml} \mathrm{LB}$ medium. DNA was partially digested with Sau3A and fragments ranging from 2 to $8 \mathrm{~kb}$ were extracted from a $0 \cdot 8 \%$ agarose gel using the Qiaquick Gel Extraction kit. These fragments were ligated into the dephosphorylated BamHI site of pUC19. The recombinant plasmids were transformed into the E. coli $\mathrm{SOD}^{-}$mutant QC871 and plated onto LB agar containing ampicillin $\left(50 \mu \mathrm{g} \mathrm{m}^{-1}\right)$ and $10 \mu \mathrm{M}$ paraquat (PQ). Chromosomal and plasmid DNA were prepared using the corresponding Qiagen kits. The inserts were sequenced by the ABI PRISM BigDye terminator cycle sequencing system (Perkin-Elmer).
Preparation of bacterial extracts and assays. The cells were harvested by centrifugation at $12000 \mathrm{~g}$ for $15 \mathrm{~min}$ at $4{ }^{\circ} \mathrm{C}$, washed with and suspended in $50 \mathrm{mM}$ sodium phosphate buffer $\mathrm{pH} 7 \cdot 8$, then stored at $-20^{\circ} \mathrm{C}$. Cells were disrupted by sonication, and after centrifugation at $12000 \mathrm{~g}$ for $15 \mathrm{~min}$ at $4{ }^{\circ} \mathrm{C}$, the supernatants (crude extracts) were stored at $4{ }^{\circ} \mathrm{C}$ for immediate use or frozen at $-20^{\circ} \mathrm{C}$.

Protein concentration was determined using a Bio-Rad DC protein assay kit. Total SOD activity from mid-exponentialphase crude extracts was estimated using the xanthine/ xanthine oxidase procedure (Beauchamp \& Fridovich, 1971). The amount of SOD required to inhibit the reduction rate of nitro blue tetrazolium by $50 \%$ was defined as one unit of activity.

The number and nature of SODs were determined by the PAGE method already described (Leclère et al., 1999). Triplicate gels were soaked in riboflavine containing $5 \mathrm{mM}$ $\mathrm{H}_{2} \mathrm{O}_{2}$ or $2 \mathrm{mM} \mathrm{KCN}$ to differentiate between Fe- and MnSOD (Droillard et al., 1989).

Cell fractionation by osmotic shock. Bacterial cells harvested after $30 \mathrm{~h}$ growth in LB medium were washed twice with $10 \mathrm{mM}$ Tris. The cells were suspended in $10 \mathrm{mM}$ Tris $/ 20 \%$ sucrose and stirred at room temperature for $15 \mathrm{~min}$, then suspended in the same buffer without sucrose and stirred again for $15 \mathrm{~min}$ in ice. The periplasmic fraction was obtained by centrifugation at $15000 \mathrm{~g}$ for $30 \mathrm{~min}$ at $4{ }^{\circ} \mathrm{C}$ and the cells were disrupted by sonication to get the cytosolic fraction.

\section{RESULTS}

\section{Gene cloning and expression of SODs}

The molecular cloning of the sod genes from $A$. hydrophila ATCC 7966 was achieved by genetic complementation of the E. coli QC871 sodA sodB double mutant. Two clones named EcA125 and EcA126 were selected; the corresponding plasmids pVLAh125 and pVLAh126 contained a $2.9 \mathrm{~kb}$ and $3.6 \mathrm{~kb}$ insert, respectively.

The ability of the plasmids to restore resistance to PQ to the $\mathrm{SOD}^{-}$double mutant of E. coli was studied by

Table 1. Bacterial strains and plasmids

\begin{tabular}{|c|c|c|}
\hline Strain or plasmid & Genotype and/or description & Source or ref. \\
\hline \multicolumn{3}{|l|}{ Plasmids } \\
\hline pUC19 & Cloning vector $; \mathrm{Ap}^{\mathrm{R}}$ & Lab. stock \\
\hline pVLAh125 & $\begin{array}{l}\text { pUC19 with } 2 \cdot 9 \mathrm{~kb} \text { insert from A. hydrophila } 7966 \text {; } \\
\text { expresses an FeSOD }\end{array}$ & This work \\
\hline pVLAh126 & $\begin{array}{l}\text { pUC19 with a } 3.6 \mathrm{~kb} \text { insert from A. hydrophila } 7966 \text {; } \\
\text { expresses a MnSOD }\end{array}$ & This work \\
\hline \multicolumn{3}{|l|}{ E. coli } \\
\hline QC868 & $\begin{array}{l}\mathrm{F}^{-} \text {leu6 thrA1 pro lac } \mathrm{Y} 1 \text { supE } 44 \text { hsdR }\left(\mathrm{r}^{-} \mathrm{m}^{+}\right) \operatorname{rpsL}\left(\mathrm{Sm}^{\mathrm{R}}\right) \\
\text { tonA1 thi1 }\end{array}$ & D. Touati \\
\hline QC871 & 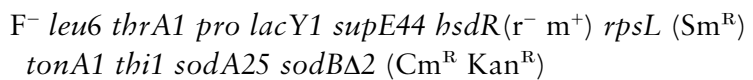 & D. Touati \\
\hline EcA125 & QC871 derivative carrying pVLAh125 & This work \\
\hline EcA126 & QC871 derivative carrying pVLAh126 & This work \\
\hline A. hydrophila & ATCC 7966 & ATCC \\
\hline
\end{tabular}


Table 2. Influence of $P Q$ on bacterial growth

Growth was evaluated by measuring $\mathrm{OD}_{600}$. See Table 1 for details of strains; Ah 7966, A. bydrophila ATCC 7966. 0, control (no PQ); PQ, $100 \mu \mathrm{M}$ PQ added at $\mathrm{OD}_{600} 0 \cdot 2$.

\begin{tabular}{|c|c|c|c|c|c|c|c|c|c|c|}
\hline \multirow{2}{*}{$\begin{array}{l}\text { Culture } \\
\text { period }(h)\end{array}$} & \multicolumn{2}{|c|}{ Ah 7966} & \multicolumn{2}{|c|}{ QC868 } & \multicolumn{2}{|c|}{ QC871 } & \multicolumn{2}{|c|}{ EcA125 } & \multicolumn{2}{|c|}{ EcA126 } \\
\hline & 0 & PQ & 0 & PQ & 0 & $P Q$ & 0 & PQ & 0 & PQ \\
\hline 6 & $3 \cdot 18$ & $3 \cdot 08$ & $2 \cdot 04$ & $2 \cdot 07$ & $1 \cdot 11$ & $0 \cdot 24$ & $1 \cdot 73$ & $1 \cdot 49$ & $1 \cdot 72$ & $1 \cdot 51$ \\
\hline 24 & $4 \cdot 56$ & 4.99 & $4 \cdot 84$ & $5 \cdot 01$ & $4 \cdot 55$ & $0 \cdot 35$ & $3 \cdot 58$ & $3 \cdot 48$ & $3 \cdot 31$ & $3 \cdot 37$ \\
\hline
\end{tabular}

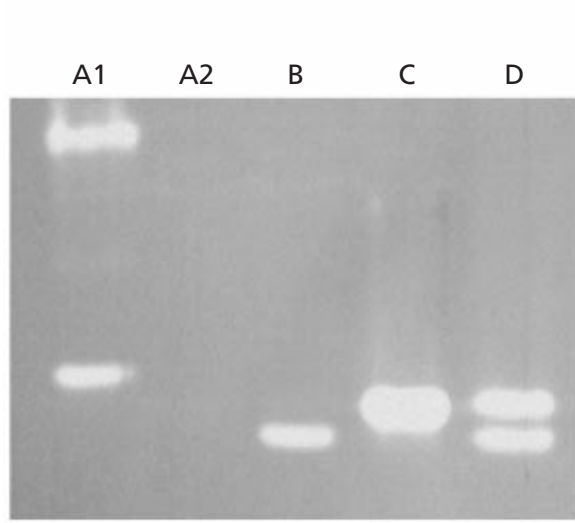

(a)

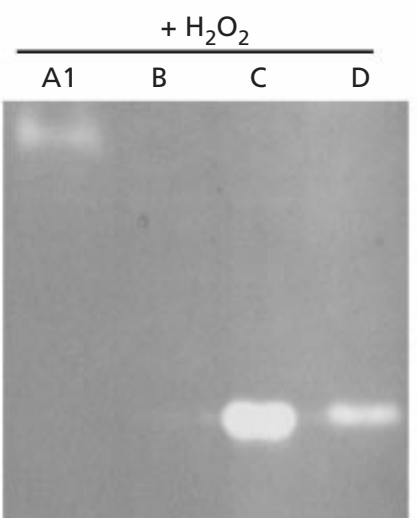

(b)

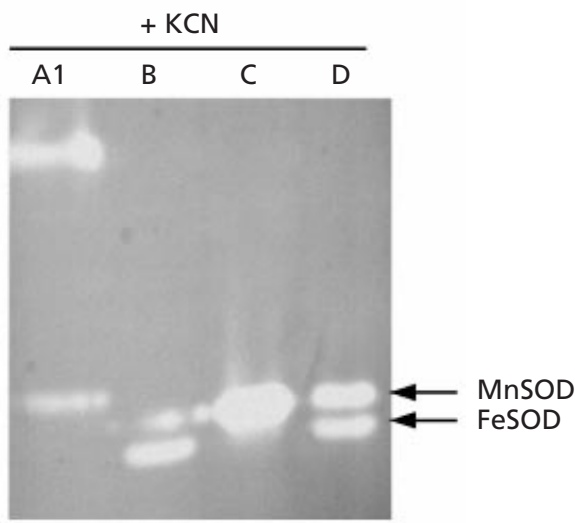

(c)

Fig. 1. Expression of SOD activities encoded by sod genes from $A$. hydrophila and inhibition patterns. Lanes: $A 1, E$. coli QC868; A2, E. coli QC871 (SOD ${ }^{-}$; B, ECA125; C, ECA126; D, A. hydrophila (Ah) ATCC 7966. Crude extracts were prepared from mid-exponential-phase $(A 1, A 2, B, C)$ or late-stationary-phase (D) bacteria. All cells were grown in LB medium. (a) Gel stained for SOD activity; (b), (c) gels treated with $5 \mathrm{mM} \mathrm{H}_{2} \mathrm{O}_{2}$ or $2 \mathrm{mM} \mathrm{KCN}$ respectively.

growth measurements in the presence of $100 \mu \mathrm{M} P Q$ (Table 2). A. hydrophila was naturally resistant to PQ at this concentration. Clones EcA125 and EcA126 showed the same PQ resistance as E. coli QC868, while E. coli QC871 $\left(\mathrm{SOD}^{-}\right)$did not grow under these conditions.

The ability of these clones to express SOD activity was tested on PAGE gels from crude cellular extracts. The mutants complemented by plasmids pVLAh125 and pVLAh126 each expressed a single SOD, while QC868 expressed two distinct activities and QC871, as expected, had no detectable SOD (Fig. 1a). The SODs expressed from EcA125 and EcA126 had different inhibition patterns and $R_{\mathrm{F}}$ values; these $R_{\mathrm{F}}$ values were 0.663 and 0.611 for A. hydrophila FeSOD and MnSOD respectively versus 0.583 and 0.265 for the corresponding enzymes of E. coli QC868 (Fig. 1b, c). Clone EcA125 produced an FeSOD as deduced by $\mathrm{H}_{2} \mathrm{O}_{2}$ inhibition and KCN resistance, whereas EcA126 synthesized a MnSOD as evidenced by resistance to both $\mathrm{H}_{2} \mathrm{O}_{2}$ and $\mathrm{KCN}$.

\section{Sequencing and analysis of the $\operatorname{sod} A$ and $\operatorname{sod} B$ genes}

After sequencing of the $2.9 \mathrm{~kb}$ insert of the plasmid pVLAh125, a fragment of about 800 bp sharing high homology with E. coli sodB gene was suspected to bear the promoter and the coding sequence for the FeSOD of A. hydrophila. The promoter region included some characteristic signals necessary for transcription: an initiation sequence $(+1$; AACA), an AT-rich region $(-10$; TTATTT) and a -35 box $(-33$; TTTGGGC). An ATG preceded by a Shine-Dalgarno sequence (GGAGA) allowed the translation of a 194-residue protein with a theoretical pI of $6 \cdot 14$ and molecular mass of $21.5 \mathrm{kDa}$. The encoded protein shared $75 \%$ homology with the E. coli FeSOD (146/194 residues) including the amino acids implicated in the metal ligand binding $\left(\mathrm{H}_{27}-\mathrm{H}_{74}\right.$ and $\left.\mathrm{D}_{158}-\mathrm{H}_{162}\right)$. A $12 \mathrm{bp}$ inverted repeat sequence followed by a stretch of Ts was found 31 bp downstream of the stop codon and could function as a rho-independent RNA polymerase terminator.

The $3.6 \mathrm{~kb}$ insert of pVLAh126 contained a complete promoter and coding sequence $(\operatorname{sod} A)$ for a protein of 204 amino acids sharing $55 \%$ identity with E. coli MnSOD (114/206 residues). A transcription initiation sequence $(+1$; AACA), an AT-rich region $(-13$; ATTAAT) and a Shine-Dalgarno box $(+5$; GAGG) were found upstream of the ATG $(+14)$. Three potential -35 boxes $\left(\mathrm{TTG}^{\mathrm{A}} /{ }_{\mathrm{T}} \mathrm{CA}\right)$ could also be found within the sequence, but the role of these sequences has not been studied. An inverted $11 \mathrm{nt}$ repeated sequence centred on 


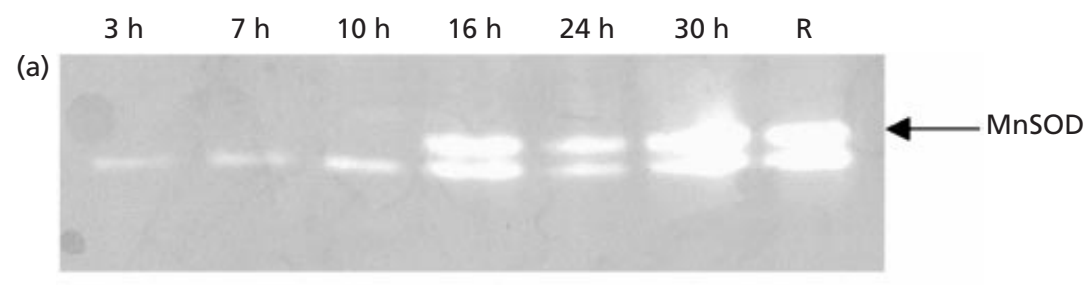

(b)

Fig. 2. Kinetics of SOD expression during $A$. hydrophila growth. Crude extracts $(10 \mu \mathrm{g}$ total protein per lane) were prepared at different time points, corresponding to different growth stages. Cells were grown in LB medium under (a) high aeration or (b) low aeration. $\mathrm{R}$, crude extract prepared from A. hydrophila grown for $48 \mathrm{~h}$ in LB medium under high aeration and used as reference.

Table 3. SOD activity in crude extracts of bacteria grown for $16 \mathrm{~h}$ in the presence of PQ

All the strains (see Table 1 for details) were grown in LB medium under high aeration, with PQ at the concentrations indicated. Values, expressed in $U$ (mg total protein $)^{-1}$ are means \pm standard deviations of triplicate assays.

\begin{tabular}{|lrrrr|}
\hline Strain & \multicolumn{4}{c|}{ PQ $(\boldsymbol{\mu M}):$} \\
\cline { 2 - 5 } & $\mathbf{0}$ & $\mathbf{1 0}$ & $\mathbf{1 0}^{\mathbf{2}}$ & \multicolumn{1}{c|}{$\mathbf{1 0}^{\mathbf{3}}$} \\
\hline E. coli QC868 & $3 \cdot 86 \pm 0 \cdot 12$ & $9 \cdot 48 \pm 0 \cdot 54$ & $20 \cdot 8 \pm 1 \cdot 27$ & $26 \cdot 47 \pm 1 \cdot 64$ \\
E. coli EcA126 & $14 \cdot 4 \pm 1 \cdot 84$ & $13 \cdot 28 \pm 1 \cdot 71$ & $17 \cdot 44 \pm 2 \cdot 21$ & $21 \cdot 87 \pm 2 \cdot 35$ \\
A. hydrophila & $6 \cdot 75 \pm 0 \cdot 83$ & $6 \cdot 41 \pm 0 \cdot 73$ & $5 \cdot 38 \pm 0 \cdot 96$ & $6 \cdot 04 \pm 1 \cdot 15$ \\
ATCC 7966 & & & & \\
\hline
\end{tabular}

nucleotide 661 with a probable hairpin structure could correspond to the rho-independent terminator sequence of the mRNA. The ORF of about $700 \mathrm{bp}$ encoded a protein with a theoretical pI of 6.07 and a molecular mass of $22 \cdot 3$. Amino acids important for the ligand binding were conserved $\left(G_{77}, G_{78}, F_{85}, Q_{150}\right.$ and $\left.D_{151}\right)$ and the 12 first amino acids constituted a potential signal peptide with the most likely cleavage site between $\mathrm{A}_{11}$ and $\mathrm{Y}_{12}$.

\section{Growth-phase-dependent expression of the MnSOD}

When E. coli QC868 was grown in LB medium under high aeration to mid-exponential phase, both FeSOD and MnSOD were detected on PAGE. EcA126 expressed the MnSOD under the same experimental conditions. A further assay, using $A$. hydrophila samples withdrawn hourly during $30 \mathrm{~h}$, showed that total SOD activity from crude extracts remained unchanged: $5.92 \pm 1.62$ units SOD (mg total protein) $)^{-1}$ at $3 \mathrm{~h}$ (mid-exponential phase) and $5.96 \pm 1 \cdot 15$ units SOD $\mathrm{mg}^{-1}$ at $16 \mathrm{~h}$ (stationary phase). On PAGE, the FeSOD was expressed whatever the growth phase whereas the MnSOD only appeared on gels after $16 \mathrm{~h}$ culture, corresponding to the stationary phase (Fig. 2a).

In other experiments using $A$. hydrophila grown under low aeration, samples were regularly assayed for SOD activity and loaded on PAGE gels. The SOD activity was identical under either high or low aeration. However, only the FeSOD was continuously detectable in crude extracts from bacteria grown under low aeration during the $30 \mathrm{~h}$ incubation period, whereas the MnSOD was never detected even after $30 \mathrm{~h}$ (Fig. 2b).

\section{Effect of iron deficiency on MnSOD synthesis}

A. hydrophila was grown in LB medium in which iron was sequestered by either chemical (DIP, EDDA) or biological (Desferal) chelators. Whatever the chelator used, an identical result was obtained: the lack of iron induced the expression of MnSOD during midexponential phase, since the MnSOD was detectable on PAGE gels after $3 \mathrm{~h}$ growth (data not shown).

\section{Effect of PQ on expression of the MnSOD}

To test the induction of the sodA gene, A. hydrophila, E. coli EcA126 and E. coli QC868 (SOD ${ }^{+}$) were grown in the presence of different concentrations of PQ (10 to $\left.10^{3} \mu \mathrm{M}\right)$. PQ at any concentration did not affect the growth rate or the final biomass and the MnSOD was not detectable on PAGE gels before the stationary phase (data not shown). The total SOD activity assayed during stationary phase $(16 \mathrm{~h})$ remained unchanged for $A$. bydrophila and slightly enhanced for pVLAh126 cloned in E. coli QC871 (strain EcA126), whereas it was strongly stimulated for E. coli QC868 (Table 3). 


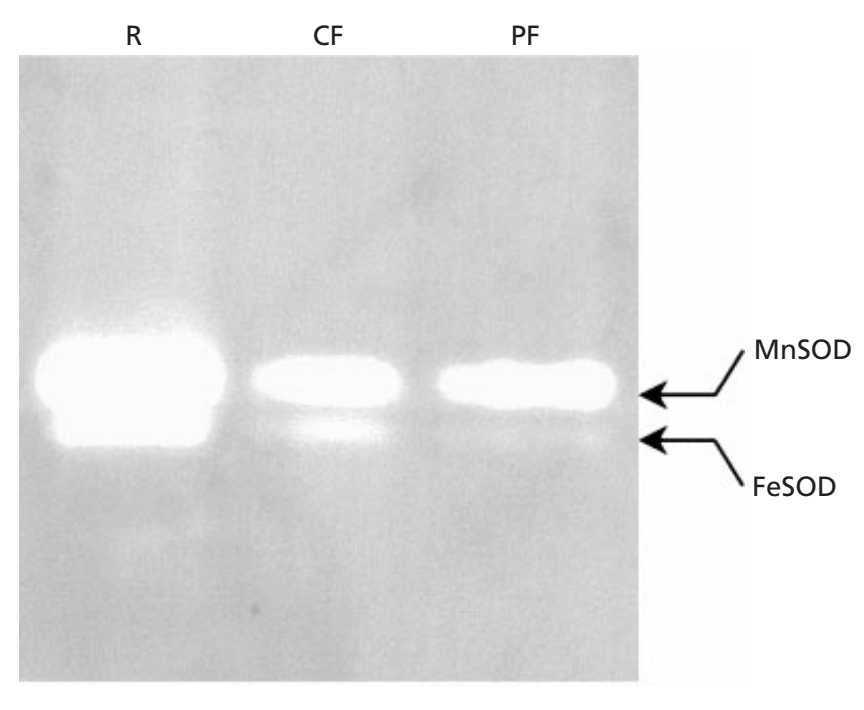

Fig. 3. Subcellular localization of $A$. hydrophila MnSOD. Cells were fractionated after $48 \mathrm{~h}$ growth in LB medium under high aeration. $R$, crude extract; CF, cytosolic fraction; PF, periplasmic fraction.

\section{Subcellular localization of the MnSOD}

A. hydrophila cells were fractionated after $48 \mathrm{~h}$ growth in $100 \mathrm{ml} \mathrm{LB}$ medium under high aeration. The SOD activity measured was $5 \cdot 18 \pm 1 \cdot 24 \mathrm{U}(\mathrm{mg} \text { total protein })^{-1}$ in the periplasmic fraction and $1.55 \pm 0.52 \mathrm{U} \mathrm{mg}^{-1}$ in the cytoplasmic fraction. For E. coli QC868, where the SODs are known to be cytoplasmic, the ratio between the two fractions was inverted $\left(4.98 \pm 0.32 \mathrm{U} \mathrm{mg}^{-1}\right.$ in the cytoplasmic fraction versus $13 \cdot 18 \mathrm{U} \mathrm{mg}^{-1}$ for the periplasmic space). PAGE of the A. hydrophila extracts showed that the MnSOD was distributed between the periplasmic and cytoplasmic fractions while the FeSOD was predominantly present in the cytoplasmic fraction (Fig. 3).

\section{DISCUSSION}

Two distinct SODs were identified in A. hydrophila ATCC 7966 and their complete genes were cloned. The sequenced insert of pVLAh125 contained an $800 \mathrm{bp}$ fragment sharing high homology with the $\operatorname{sodB}$ gene from E. coli (Carlioz et al., 1988). The protein exhibited $75 \%$ identity with the E. coli FeSOD, and the activity expressed corresponded to an FeSOD as determined by the inhibition patterns.

A positive effect of the iron-dependent regulatory Fur protein has been observed in the expression of the $\operatorname{sodB}$ gene of E. coli (Niederhoffer et al., 1990) and recently the site of Fur regulation has been found in the promoter region. The site functioned as an extended -10 promoter containing a TGN sequence near the TA-rich region (Dubrac \& Touati, 2000). Nevertheless the $A$. bydrophila FeSOD seemed to be constitutively expressed since the environmental changes such as iron limitation tested in this study did not affect its synthesis; moreover, the A. hydrophila sodB promoter did not show the TGN sequence and so could be unaffected by the Fur regulator.

The sequenced insert of pVLAh126 contained a $700 \mathrm{bp}$ gene encoding a MnSOD displaying 55\% identity with the E. coli MnSOD (Takeda \& Avila, 1986). The amino acids implicated in the metal binding, the $\mathrm{Y}_{34}$ playing a catalytic role (Hunter et al., 1997), and those pinpointed as potential discriminators between the iron and manganese proteins $\left(\mathrm{G}_{77}, \mathrm{G}_{78}, \mathrm{~F}_{85}, \mathrm{~N}_{149}, \mathrm{Q}_{150}, \mathrm{D}_{151}\right.$ and $\left.\mathrm{V}_{189}\right)$ (Parker \& Blake, 1988), were conserved. A conservative change between the $\mathrm{K}_{29}$ responsible for electrostatic steering of the substrate and an arginine residue was observed. The amino-terminal part of the protein $(65$ residues) shared high homology $(71 \%)$ with that of $E$. coli. Nevertheless, although 9 out of the 12 first residues were conserved (MSHTLPLALYAY for A. bydrophila vs MSYTLPSLPYAY for E. coli), the A. hydrophila MnSOD contained a potential signal sequence lacking in E. coli $\mathrm{Fe}-$ and MnSODs (Nielsen et al., 1997). A similar potential sequence suggesting a periplasmic location of the enzyme has been described in Acinetobacter calcoaceticus MnSOD (23 amino-terminal residues) (Geißdörfer et al., 1997). In the fish pathogen Aeromonas salmonicida a periplasmic MnSOD has also been detected (Barnes et al., 1996) and a role in the pathogenicity was proposed by the authors. This SOD may play a role in the defence against external reactive oxygen species like the periplasmic $\mathrm{Cu} / \mathrm{ZnSOD}$ found in E. coli (Benov \& Frodovich, 1996), Legionella pneumophila (Saint-John \& Steinmann, 1996), Haemophilus influenzae and H. parainfluenzae (Kroll et al., 1991, 1995). Recently, the molecular analysis of genetic differences between virulent and avirulent strains of $A$. bydrophila isolated from diseased fish did not indicate SODs as virulence factors (Zhang et al., 2000).

As mentioned by Barnes et al. (1996) for A. salmonicida, the MnSOD of A. hydrophila was induced when no iron was available in the medium. In E. $\operatorname{coli}, \operatorname{sod} A$ was regulated by the Fur repressor binding to iron boxes, consensus sequences NAT ${ }^{\mathrm{A}} /{ }_{\mathrm{T}} \mathrm{AT}$ (Escolar et al., 1998), present in the promoter. These iron-regulatory sequences were not found in the region $300 \mathrm{bp}$ upstream of the sodA gene of A. hydrophila although a Fur protein was present in the wild-type A. hydrophila 495A2 (Barghouthi et al., 1991). So it remains unclear whether the regulation is Fur-dependent, and further investigation is necessary to determine the mechanism of regulation of $\operatorname{sod} A$ by iron.

In LB medium, the A. hydrophila MnSOD was only expressed in the stationary phase under high aeration, even with an excess of iron (data not shown). These results are in accordance with the high expression of MnSOD in response to elevated oxygen levels and upon changes in growth phase in E. coli (Compan \& Touati, 1993). Similarly increased levels of SOD activity during stationary phase were observed in other bacterial genera (Saint-John \& Steinmann, 1996; Inaoka et al., 1998; Clements et al., 1999). The authors suggested that enhanced SOD levels are connected with survival of the bacterial cells under stressed conditions. The expression 
of a MnSOD can also be related to quorum sensing, as was recently demonstrated for Pseudomonas aeruginosa (Bollinger et al., 2001).

The sodA gene of A. hydrophila was not regulated by addition of PQ to the medium even in E. coli EcA126 although PQ enters the cells, supported by the fact that the expression was strongly stimulated by PQ in E. coli QC868. This non-regulation by PQ may not be so surprising considering the periplasmic location of the MnSOD in A. hydrophila and the increased flux of intracellular superoxide caused by PQ (Hassan, 1984). Physiological studies are necessary to determine the precise function of the MnSOD for Aeromonas.

Lastly, considering the particular conditions of the MnSOD expression in A. hydrophila described in this paper, together with the previously reported occurrence of this enzyme in A. salmonicida (Barnes et al., 1996) it now appears clear that the presence of a unique SOD in Vibrionaceae should no longer be taken into account to distinguish this family from Enterobacteriaceae.

\section{ACKNOWLEDGEMENTS}

V. Leclère is indebted to Dr D. Touati (Université de Paris VII, France) for the generous gift of double mutant E. coli QC871 and its $s o d^{+}$homologue QC868. This work was supported by grants from the Université des Sciences et Technologies de Lille, the Région Nord-Pas de Calais and the Fond Européen pour le Développement de la Recherche.

\section{REFERENCES}

Barghouthi, R., Payne, S. M., Arceneaux, J. E. L. \& Byers, B. R. (1991). Cloning, mutagenesis, and nucleotide sequence of a siderophore biosynthetic gene (amoA) from Aeromonas hydrophila. J Bacteriol 173, 5121-5128.

Barnes, A. C., Horne, M. T. \& Ellis, A. E. (1996). Effect of iron on expression of superoxide dismutase by Aeromonas salmonicida and associated resistance to superoxide anion. FEMS Microbiol Lett 142, 19-26.

Baumann, P. \& Schubert, R. H. W. (1984). Vibrionaceae. In Bergey's Manual of Systematic Bacteriology, vol. 1, pp. 516-550. Edited by N. R. Krieg \& J. G. Holt. Baltimore: Williams \& Wilkins.

Beauchamp, C. \& Fridovich, I. (1971). Superoxide dismutase: improved assays and an assay applicable to acrylamide gels. Anal Biochem 44, 276-287.

Benov, L. \& Fridovich, I. (1996). Functional significance of the $\mathrm{Cu}, \mathrm{ZnSOD}$ in Escherichia coli. Arch Biochem Biophys 327, 249-253.

Benov, L., Chang, L. Y., Day, B. \& Fridovich, I. (1995). Copper, zinc superoxide dismutase in Escherichia coli: periplasmic localization. Arch Biochem Biophys 319, 508-511.

Bollinger, N., Hassett, D. J., Iglewski, B. H., Costerton, J. W. \& McDermott, T. R. (2001). Gene expression in Pseudomonas aeruginosa: evidence of iron override effects on quorum sensing and biofilm-specific gene regulation. J Bacteriol 183, 1990-1996.

Carlioz, A., Ludwig, M. L., Stallings, W. C., Fee, J. A., Steinmann, H. M. \& Touati, D. (1988). Iron superoxide dismutase: nucleotide sequence of the gene from Escherichia coli $\mathrm{K} 12$ and correlations with crystal structures. J Biol Chem 263, 1555-1562.

Clements, M. O., Watson, S. P. \& Foster, S. J. (1999). Charac- terization of the major superoxide dismutase of Staphylococcus aureus and its role in starvation survival, stress resistance, and pathogenicity. J Bacteriol 181, 3898-3903.

Colwell, R. R., MacDonell, M. T. \& De Ley, J. (1986). Proposal to recognize the family Aeromonadaceae fam. nov. Int J Syst Bacteriol 36, 473-477.

Compan, I. \& Touati, D. (1993). Interaction of six global transcription regulators in expression of manganese superoxide dismutase in Escherichia coli K-12. J Bacteriol 175, 1687-1696.

Demple, B. (1991). Regulation of bacterial oxidative stress genes. Annu Rev Genet 25, 315-337.

Droillard, M. J., Bureau, D., Paulin, A. \& Daussart, J. (1989). Identification of different classes of superoxide dismutase in carnation petals. Electrophoresis 10, 44-68.

Dubrac, S. \& Touati, D. (2000). Fur positive regulation of iron superoxide dismutase in Escherichia coli: functional analysis of the sodB promoter. J Bacteriol 182, 3802-3808.

Escolar, L., Pérez-Martin, J. \& de Lorenzo, V. (1998). Binding of the Fur (ferric uptake regulator) repressor of Escherichia coli to arrays of the GATAAT sequence. J Mol Biol 283, 537-547.

Fridovich, I. (1986). Superoxide dismutases. Adv Enzymol 58, 61-97.

Geißdörfer, W., Ratajczak, A. \& Wolfgang, H. (1997). Nucleotide sequence of a putative periplasmic $M n$ superoxide dismutase from Acinetobacter calcoaceticus ADP1. Gene 186, 305-308.

Hassan, H. M. (1984). Determination of microbial damage caused by oxygen free radicals, and the protective role of superoxide dismutase. Methods Enzymol 105, 404-412.

Hunter, T., Ikebukuro, K., Bannister, W. H., Bannister, J. V. \& Hunter, G. J. (1997). The conserved residue tyrosine 34 is essential for maximal activity of iron-superoxide dismutase from Escherichia coli. Biochemistry 36, 4925-4933.

Inaoka, T., Matsumura, Y. \& Tsuchido, T. (1998). Molecular cloning and nucleotide sequence of the superoxide dismutase gene and characterization of its product from Bacillus subtilis. J Bacteriol 180, 3697-3703.

Kirov, S. M. (1997). Aeromonas and Plesiomonas species. In Food Microbiology: Fundamentals and Frontiers, pp. 265-287. Edited by M. P. Doyle, L. R. Beuchat \& T. J. Montville. Washington, DC: American Society for Microbiology.

Kroll, J. S., Langford, P. R. \& Loynds, B. (1991). Copper-zinc superoxide dismutase of Haemophilus influenzae and H. parainfluenzae. J Bacteriol 173, 7449-7457.

Kroll, J. S., Langford, P. R., Wilks, K. E. \& Keil, A. D. (1995). Bacterial $[\mathrm{Cu}, \mathrm{Zn}]$-superoxide dismutase: phylogenetically distinct from the eukaryotic enzyme, and not so rare after all! Microbiology 141, 2271-2279.

Leclère, V., Boiron, P. \& Blondeau, R. (1999). Diversity of superoxide-dismutases among clinical and soil isolates of Streptomyces species. Curr Microbiol 39, 365-368.

Merino, S., Rubires, X., Knochel, S. \& Tomas, J. M. (1995). Emerging pathogens: Aeromonas spp. Int J Food Microbiol 28, 157-168.

Niederhoffer, E. C., Najanro, C. M., Bradley, K. L. \& Fee, J. A. (1990). Control of Escherichia coli superoxide dismutase (sodA and $\operatorname{sod} B$ ) genes by the ferric uptake regulation (fur) locus. $J$ Bacteriol 172, 1930-1938.

Nielsen, H., Engelbrecht, J., Brunak, S. \& Von Heijne, G. (1997). Identification of prokaryotic and eukaryotic signal peptides and prediction of their cleavage sites. Protein Eng 10, 1-6.

Parker, M. W. \& Blake, C. C. F. (1988). Iron- and manganese- 
containing superoxide dismutases can be distinguished by analysis of their primary structures. FEBS Lett 229, 377-382.

Saint-John, G. \& Steinmann, H. M. (1996). Periplasmic copperzinc superoxide dismutase of Legionella pneumophila: role in stationary-phase survival. J Bacteriol 178, 1578-1584.

Takeda, Y. \& Avila, H. (1986). Structure and gene expression of the E. coli Mn-superoxide dismutase gene. Nucleic Acids Res 14, 4577-4589.

Youn, H.-D., Kim, E.-J., Roe, J.-H., Hah, Y. C. \& Kang, S.-O. (1996).
A novel nickel containing superoxide dismutase from Streptomyces spp. Biochem J 318, 889-896.

Zhang, Y. L., Ong, C. T. \& Leung, K. Y. (2000). Molecular analysis of genetic differences between virulent and avirulent strains of Aeromonas hydrophila isolated from diseased fish. Microbiology 146, 999-1009.

Received 26 March 2001; revised 4 June 2001; accepted 13 July 2001. 